〈書 評〉

\section{厳 善平著}

\section{『農民国家の課題』}

〈2002 年 10 月 ・ 名古屋大学出版会〉

青 柳斉

昨今の中国人留学生や中国農村研究者の増大等を反 映して, 中国農村経済関連を標題とする出版図書は多 くなってきた。但し，書籍名に反して，中身は食料問 題や農業構造問題など特定分野に偏っている例が大半 であり，中には統一性を欠いた既発表論文集の場合も 少なくない，これに対して，本書は全て著者の書き下 ろしで, 制度史的な検討と関連データやその計量分析 に基づきながら，中国農村・農業経済に関する主要な 問題を取り上げ，その論点を要領よくまとめている. また，政策の評価や諸問題の展望等に関しては，著者 の見解とともに諸説も紹介しており，複眼的な視点で 捉えようとしている。，その意味で，本書は既存の研究 成果が凝縮されており決して易しくはないが，中国農 村・農業経済問題の入門書としても格好の文献と思わ れる. 以下，本書の梗概について紹介してみよう。

まず, 第 1 章の「現代中国の農村・農業・農民」で は，国民経済における農業部門の相対的地位の変化や 成長メカニズム, 農業経営及び農家経済の具体的な諸 相, そして国際比較からみた中国農業の特質に関して, 関連統計等を用いながら定量的な分析を行っている. そこでは，都市化を伴わない工業化の発展戦略が歪ん だ経済・社会構造を作り上げ，今日の農村・農業の貧 困問題をもたらしたこと，また，農外労働市場が拡大 したにも関わらず農地の流動化や階層分化が進まず, それが中国農業の大半を零細な小農経営に留めている と解説する。 そして, 農業インフラ整備等が遅れてい るもとでの農産物商品化率の上昇は, 農業経営の零細 性とともに経営効率性の向上や生産の安定を妨げてい るという。ささらに, 耕地面積規模や土地・労働生産性 等の国際比較を通して, 中国農業がアジア型の性質を 帯びながら, 就業構造の高度化が経済発展に比べて遅 れていると特徴づける.

第 2 章の「農村経済制度の変遷」では, 農業集団化 の歷史や人民公社体制の成立々崩壞, 農村基層組織の 変遷, 主要な農村経済制度の改革について概説してい
る. 革命政権以後, 毛沢東が進めた農業の集団化やそ の後の人民公社制度の展開は, 結果的に農業の停滞と 農民の貧困をもたらした，そして，毛沢東の逝去を契 機に一部の地域で家族経営請負制度が普及し, 中央政 府が追認しその後は主要政策として採用されていっ た。 その後, 全国的な家族農業経営制度の進展にとも ない, 農地流動化や農産物流通の自由化, 戸別経営の 協同的補完関係の強化などの制度改革が進められた。 但し, 一連の制度改革は, 中国農村の市場経済化に対 応した政策であるが，今日においても不完全な段階に あると指摘する。

第 3 章の「都市と農村の二重構造」では，二重社会 構造の実態とその制度的基礎を取り上げる、計画経済 の時代においては, 戸籍制度が就職や福祉, 保険など と一体化され，農業戸籍をもつ農民の都市一の移住な らびに職業選択の自由が厳しく制限されていた。改革 開放時代に入ってからは, 企業家的農民によって農村 工業が勃興し, 一部の農民は都市部一移動し多様な職 種に従事するようになった。しかし，現在でも農民に 対しては，都市住民と同等の仕事を得る自由な選択機 会が保障されていない，著者は，このような農村・都 市間の社会的待遇格差が大きく, 人為的な差別政策に よって構造化されているという.

第 4 章の「農民と国家の関係」では，農民負担の変 遷と「税費改革」の現状，村民自治の仕組みと選挙制 度の改革を取り上げている，農民の実質的な公的負担 は, 農業諸税以外の各種課徴金や労衝負担をも含める と改革開放以後になって急増し, 都市住民に比へて高 い水準にあること，他方，負担の軽減を意図した「税 費改革」は郷鎮・村財政の逼迫をもたらし改革は頓挫 しているという。また, 村民自治制度の導入は本来, 国家と農民の政治的支配関係を根底から変えるもので あるが，その施行過程で郷鎮政府と村党支部の影響力 は依然として大きく, 制度の理想と現実との間には大 きなギャップがあるという，なお，村民自治の有効性 に対して, 農民の教育水準の低さや宗族勢力の影響か ら疑問視する声もあるが, それは根本的な問題でなく, 上級の党組織から任命される村党支部書記や郷鎮政府 と，村民委員会との関係をどうすべきかがより大きな 問題だという. そのため, 政府内で検討されている党 支部と村委員会の一体化案に対して, 郷鎮以上の各級 組織において, 党の絶対的支配という前提が変わらな い限り, 両者の一体化は実質的に難しいと批評する.

第 5 章の「郷鎮企業の成長と転換」では, まず郷鎮 企業の展開過程やその国民経済的意義を概説し, 郷鎮 企業の成長要因の計量分析や代表的な成長モデルを紹 介して,さらに郷鎮企業の所有制度改革の現状を取り 上げている，そこでは，鄉鎮企業は国民経済の高度成 
長に大きく貢献したこと, 市場経済の進展に対応して, 郷村企業から私有化の企業制度に变革しつつあると紹 介している. 但し, 大半の郷鎮企業は規模が零細で, その展開の度合いも地域的に偏在しており，インフラ 条件の悪い内陸奥地の郷鎮企業は経営不振に陥ってい る. そして, 農村余剩労働力の吸収や農家所得の向上 にとって，郷鎮企業の持続的成長は必須条件であり， 融資制度の整備など政策的支援が必要だという.

第 6 章の「農村労働力の地域閒異動」では，労働移 動制度の変遷や農村労働移動の決定要因に関する計量 的分析, 農村労働移動の私経済的成果や社会的波及効 果・問題を取り上げている，そこでは，農地の集団所 有制により都市への出稼ぎ農民は本来的に「余剒労働 力」であること, 戸籍や出身地等の属性による労働市 場の階層化は, 出稼ぎ労働者の流入による就職競争の 激化を労働市場の下層部分に限定する効果があること を実証し，国家の社会に対する強い統治能力が無秩序 な労働移動による社会混乱を回避しうるという.

第 7 章の「食糧問題の実態」では, 食糧の生産増加 とその要因分析, 款物主産地の地域移動や食糧の消費 動向, 中長期的な食糧需給の展望について取り上げる. そこでは, 増産の主因は耕地面積と作付面積の拡大で はなく単収の向上であると指摘する. 地域的には, 特 に東北部の食糧生産能力の向上が大きく寄与した。ま た, 食糧の消費面では, 澱粉質食料の需要量が減少し た一方で動物性食料などが増大し, その結果として食 糧の総需要量が増大している. 他方, 食糧の直接消費 は飽和状態に達しており, 今後は所得の増大に伴い直 接消費の食糧は減少すると展望する。 そして, 対外公 約の食糧自給率 95\%以上を実現するためには, 人口抑 制政策の継続に加えて, 水利施設や農業基盤整備を強 化していくこと, さらに, 国際競争への対応として大 規模農業経営の育成を進めていく必要があるという。

最後の第 8 章「農業の国際化とWTO 加盟」では, 最近, ホットな話題になっているWTO 加盟後の中国
国内農業への影響問題や農産物貿易の動向を取り上げ ている，そこでは，労働集約型の園芸農産物が中国農 業にとって比較優位をもつため今後の成長期待が高い こと, そのさい, 農産物輸出で首位を占める日本市場 が大きな意義を持っているという，また，WTO 加盟 の国内農業への影響に関しては諸説を紹介して, 土地 利用型から労衝集約型農業の拡大で, 農村余剩労働力 の吸收が進むという見方が中国国内では主流であると いう。他方, 国際的に不安定な食糧市場の問題を重視 して, 完全な自由化政策に対しては慎重論もある。い ずれにせよ著者は, WTO 加盟や市場開放のために損 失を受ける階層や地域の農民に対して, どのように補 償していくかが今後の政策的課題になるという.

以上の中国農村経済に関する歴史・現状認識や政策 評価等に対して, 筆者は全く同感であり特に異論もな い.むしろ, 中国問題プロパーの研究者として, 精力 的な実態調査を重ねてきた著者の深い洞察に教えられ た点が少なくない, 本書を通読して, 「農民国家の課 題」(中国農村経済の今日的課題) は何かと改めて問 えば, それは「農村貧困問題の解決」につきるように 思われる. 農村・都市の二重構造格差はもとより, 農 地割り当て制度の維持や主要食糧の価格維持政策, 農 村郷鎮企業の成長と停滞の影響, 農村からの大都市一 の労働力移動摩擦, 農村自治制度の改革と限界, WTO 加盟の影響問題など，す心゙てが農村貧困問題の発生・ 増幅あるいはその縮小の展望と密接に関連している. この問題の解消には, よりいっそうの市場経済化とそ れに対応した制度化の徹底が求められるのか, それと も「行き過ぎた」市場経済化の見直し（修正）が必要 なのか. 著者は前者を強調しているが, 後者の視点で の問題提起もありうるであろう。なお，本書に欲張り な注文をすれば，中国政府の直接的な農村貧困対策や 農業関連の環境問題にも言及して欲しかった。

(著者：新潟大学農学部) 